\title{
Palaeopathological Evidence Suggesting Multiple Myeloma in a Skull from the Edo Period of Japan
}

\author{
Takao Suzuki \\ Department of Anthropology, \\ Faculty of Science, \\ The University of Tokyo
}

\begin{abstract}
The skull of an adult male in the Edo period of Japan was investigated and diagnosed palaeopathologically as multiple myeloma. The pathological changes represented the form of punched out lesions widely scattered in the entire skull.

The differential diagnosis between metastatic carcinoma and multiple myeloma was discussed from morphological and roentgenological point of view.

This is the first palaeopathological case report on a malignant neoplasm in the excavated human skeletal remains from Japan.
\end{abstract}

The tumors, especially malignant cases which produce the extensive changes on the bone are quite uncommon in earlier populations. At present, some palaeopathological findings have been reported (SUzUKI, 1978), however, no case of malignant neoplasm in the skeletal remains has been reported in Japan. The reason why the reports are very scanty might be the followings. First, an average length of life in the earlier populations is thought to be shorter than that in the modern populations (КовAYASHI, 1967), so that the ancient people died from many other causes before they were involved with malignant neoplasm. The second problem may regard the cause of death. The ancient people were conceivably subject to various infectious diseases (pyogenic infection) rather than malignant tumors as a cause of death. Third,

Article No. 8009 the most important reason seems to be in the difficulty of diagnosing various palaeopathological changes in the bones. When we observe the osteoplastic or osteolytic changes in the bones, we are of ten troubled in deciding whether the changes are caused by the infectious diseases such as periostitis, osteomyelitis, spirochetal disease, etc. or by the malignant tumors of bone such as osteosarcoma, secondary metastatic carcinoma, meningioma and multiple myeloma.

In the course of examination of the palaeopathological changes on the skeletal remains from the Edo period (16031867) in Japan, a skull diagnosed as multiple myeloma has been found by the author.

\section{MATERIAL}

The skull investigated remarkable, pathological changes is one from the skeletal 
series which were excavated and collected at Muen-zaka in Yushima, Tokyo, in 1955 by Dr. T. KAwAGoE of Jikei University School of Medicine. The skeletal remains from Muen-zaka containing about 300 skulls would be those of the citizens of Edo (old Tokyo), and they are presumed to be burried in the Edo period about 171-272 years ago (KAWAGoE, 1957). The cranial measurements and observations of the Muen-zaka series were reported by KAWAGOE in 1957 and by MORITA \& KAWAGOE in 1960.

The skull, catalogued as Muen-40, in the Department of Anatomy, Jikei University School of Medicine, is the isolated skull of an adult male. The neurocranium and facial skeleton are well-preserved without any deformations or destructions.

\section{MEASUREMENTS AND OBSERVATIONS}

The measurements and indices of the Muen-40 skull are given in Table 1 . The maximum cranial length $(182 \mathrm{~mm})$ is not far from the male average $(183.2 \mathrm{~mm})$ of the Muen-zaka series. The maximum cranial breadth (136 $\mathrm{mm}$ ) is fairly smaller (about $-1 \sigma)$ than the average $(140.8 \mathrm{~mm})$. The cranial length-breadth index (74.73) represents dolichocranic type, and that is comparatively smaller than the male average of the Muen-zaka series (77.0).

The facial skeleton of Muen-40 is more delicate in constitution than that of the average male of the Edo period. Total facial length (94 $\mathrm{mm}$ ) and bi-zygomatic breadth $(130 \mathrm{~mm})$ are slightly small. The KollmanN's upper facial index (54.62)
Table 1. Cranial measurments and indices of Muen-40

\begin{tabular}{|c|c|c|}
\hline MARTIN's No. & Measurments & $(\mathrm{mm})$ \\
\hline \multicolumn{2}{|c|}{1 Maximum cranial length } & 182 \\
\hline \multicolumn{2}{|c|}{5 Basion-nasion length } & 103 \\
\hline \multicolumn{2}{|c|}{8 Maximum cranial breadth } & 136 \\
\hline \multicolumn{2}{|c|}{9 Minimum frontal diameter } & 90 \\
\hline \multicolumn{2}{|c|}{10 Maximum frontal diameter } & 115 \\
\hline \multicolumn{2}{|c|}{11 Biauricular breadth } & 126 \\
\hline \multicolumn{2}{|c|}{13 Mastoideal breadth } & 107 \\
\hline \multicolumn{2}{|c|}{17 Basion-bregma height } & 144 \\
\hline \multicolumn{2}{|c|}{29 Frontal chord } & 110 \\
\hline \multicolumn{2}{|c|}{30 Parietal chord } & 101 \\
\hline \multicolumn{2}{|c|}{31 Occipital chord } & 117 \\
\hline \multicolumn{2}{|c|}{40 Basion-prosthion length } & 94 \\
\hline \multicolumn{2}{|c|}{43 Upper facial breadth } & 101 \\
\hline \multicolumn{2}{|c|}{45 Bizygomatic diameter } & 130 \\
\hline \multicolumn{2}{|c|}{46 Mid-facial breadth } & 99 \\
\hline \multicolumn{2}{|c|}{48 Upper facial height } & 71 \\
\hline \multicolumn{2}{|c|}{51 Orbital breadth (1) } & 43 \\
\hline \multicolumn{2}{|c|}{52 Orbital height(1) } & 36 \\
\hline \multicolumn{2}{|c|}{54 Nasal breadth } & 28 \\
\hline \multicolumn{2}{|c|}{55 Nasal height } & 52 \\
\hline \multicolumn{2}{|c|}{57 Minimum bre } & 8 \\
\hline Martin's No. & \multicolumn{2}{|l|}{ Indices } \\
\hline $8: 1$ & Length-breadth index & 74.7 \\
\hline $17: 1$ & Length-height index & 79.1 \\
\hline $17: 8$ & Breadth-height index & 105.9 \\
\hline $9: 10$ & Transverse frontal index & 78.3 \\
\hline$(1+8+17) / 3$ & Cranial module & 154.0 \\
\hline $48: 45$ & Upper facial index & 54.6 \\
\hline $52: 51$ & Orbital index & 83.7 \\
\hline $54: 55$ & Nasal index & 53.9 \\
\hline$(40+45+48) / 3$ & 3 Upper facial module & 98.3 \\
\hline $40: 1$ & Longitudinal & \\
\hline & craniofacial index & 51.2 \\
\hline $45: 8$ & Transverse craniofacial & \\
\hline & index & 95.6 \\
\hline
\end{tabular}

belongs to the "mesēn" type. Orbital index (83.72) and nasal index (53.85) show no marked differences from the other Muen-zaka males.

In the inspection of the Muen-40 skull, 


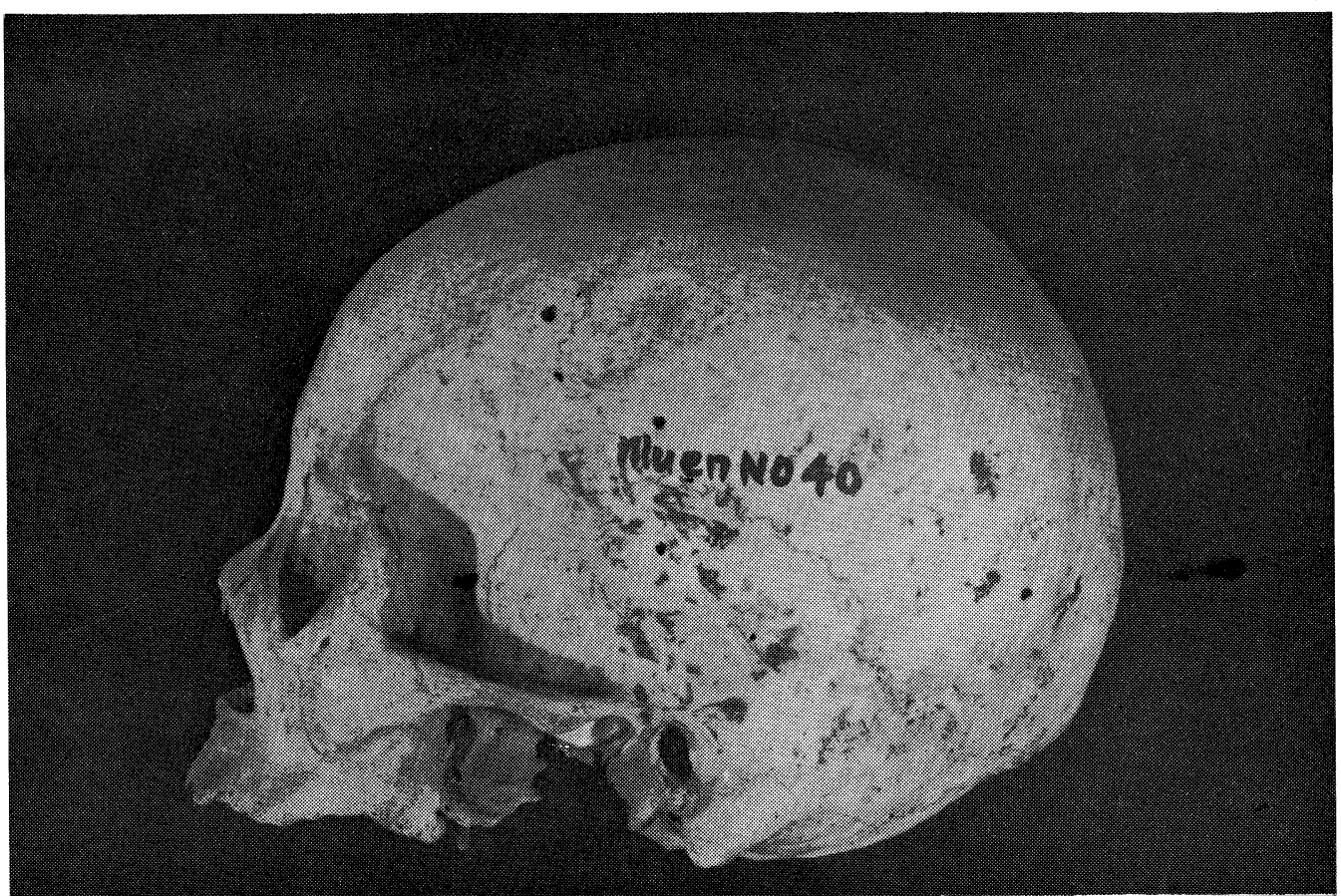

Fig.1. Lateral view of an adult skull of the Edo period. The skull (Muen-40) collected by Dr. KaWAGOE clearly shows the pathological lesions.

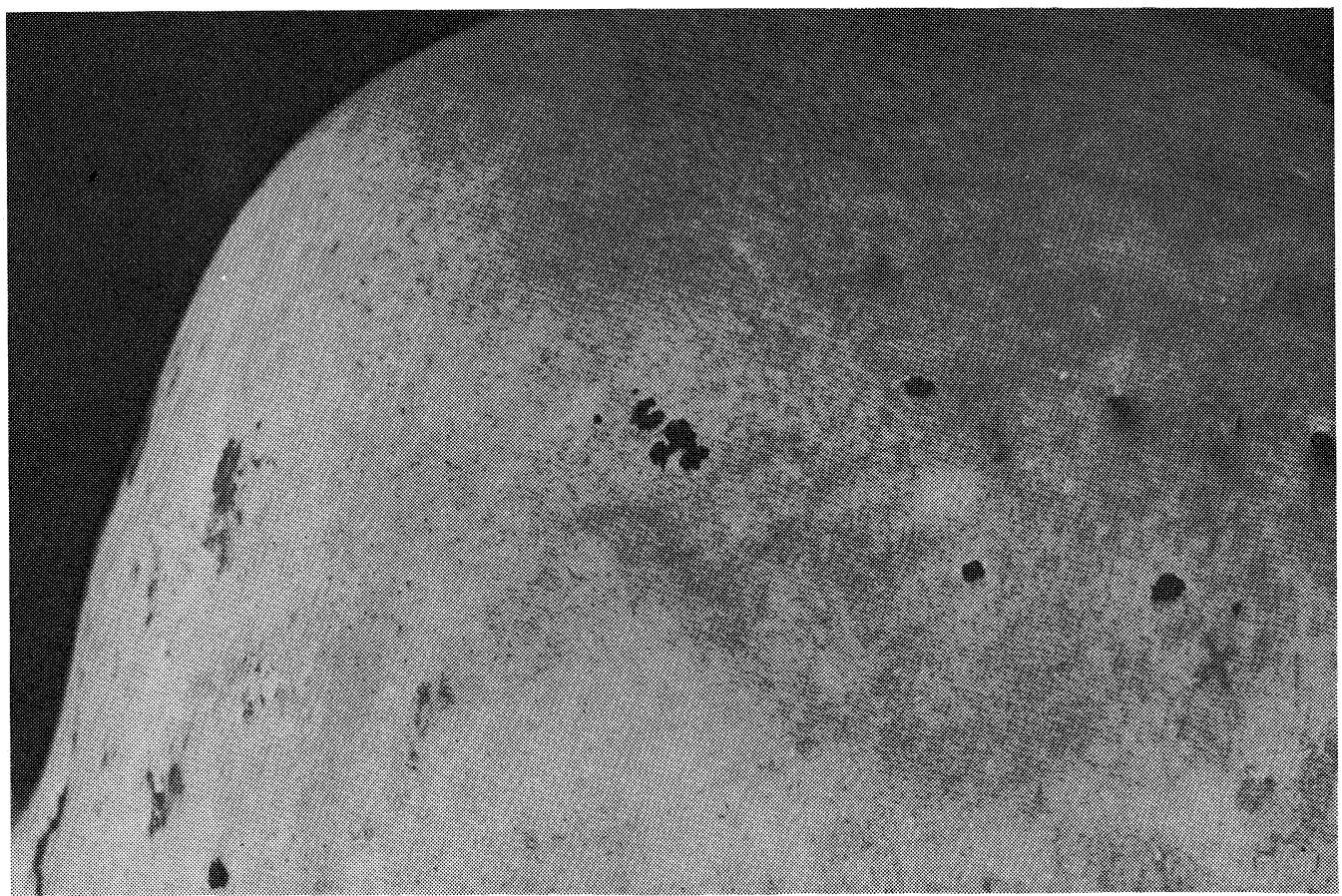

Fig. 2. Close-up view of the parietal region. This illustrates clear rounded punched out lesions. There are no signs of bone sclerosis. 


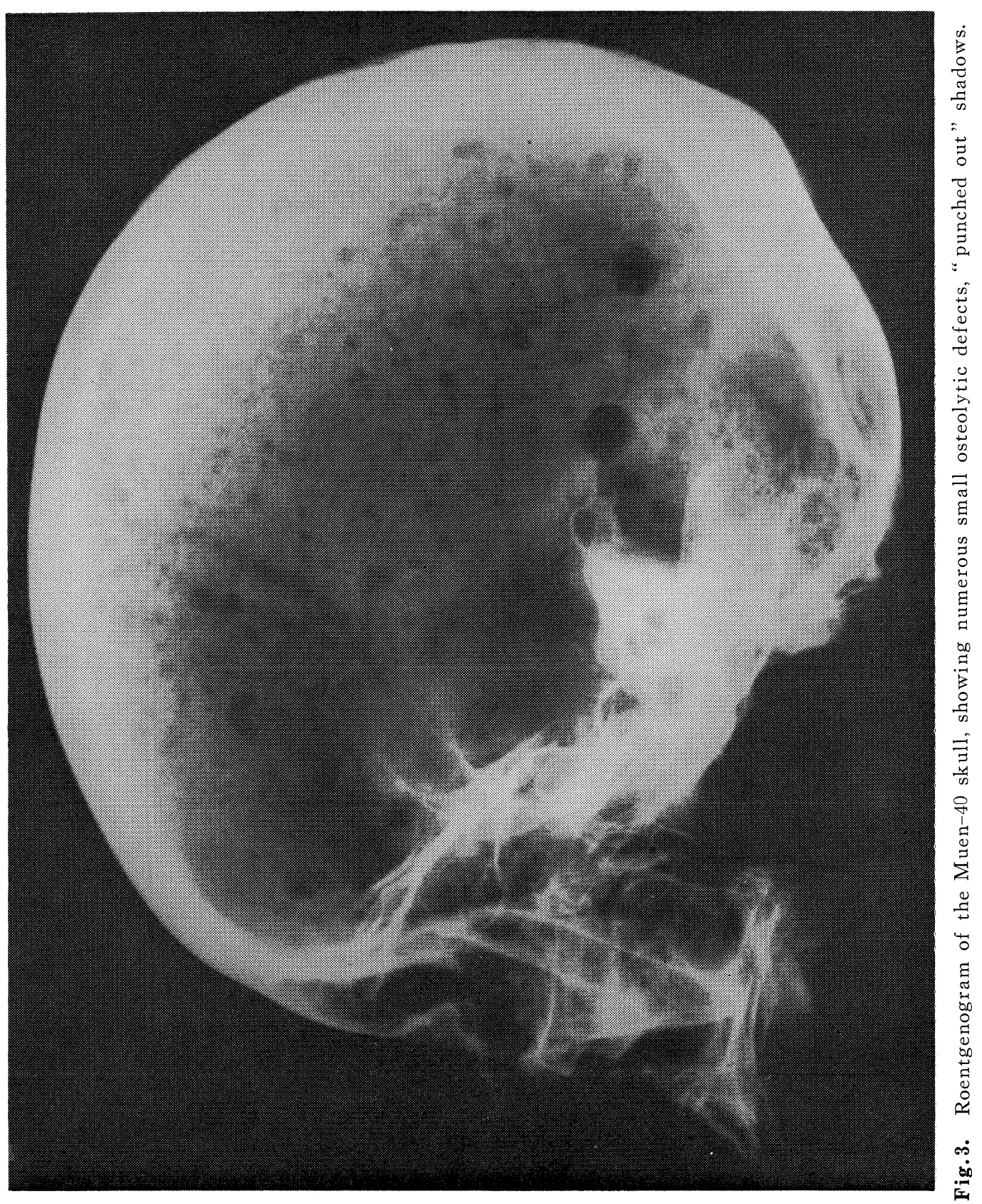


the endocranial and ectocranial sutures of the skull are obliterated, that is corresponding with grade 4 (totally closed) of the FRÉDÉRIC's scale of suture closure. In most part of the alveolar region of the maxilla, considerable alveolar bone resorption is in process, probably due to periodontal disease. Especially in the bilateral molar areas, the irregular hyperostosis and the rounded chronic abscess cavity opening to the external surface of the bone are recognized. Such conditions suggest that the age at death of this individual might have been more than 40 years of age.

In the vertical view, cranial type belongs to the oval shape. Parietal foramina are present on both sides. Parietal eminences are not so developed.

In the lateral view, the frontal region of the vault is moderate by prominent in profile. Superior temporal lines are also moderate. Porus acusticus externus is oval in shape, and no aural exostosis is present on either side. Pterion region shows H-shaped pattern. Mastoid processes are well-developed.

In the frontal view, the glabella and superciliary arches are moderately developed, and frontal eminences are indistinct. A supraorbital nerve groove is present on the right side. Metopic suture is absent.

In the occipital view, the vault contour is so called "Hausform". External occipital protuberance is developed moderately, and the superior nuchal lines are faint. There is no indication of Inca bone. The hypoglossal canal is not branched in its course bilaterally.
The skull exhibits more than 20 small (3 to $8 \mathrm{~mm}$ in diameter) punched out lesions in the frontal, parietal, temporal, and occipital bones. Those destructive lesions which penetrate through the inner and outer tables represent the form of clear rounded lesions. There are no signs of bone sclerosis around the perforated lesions and no inflammatory irregular hyperostosis on the surface of the skull. The largest lesion exists near the right asterion, and its diameter is about $8 \mathrm{~mm}$ (Figs. $1 \& 2$ ).

The roentgenogram shown in Fig. 3 reveals innumerable clear rounded "punched out" shadows which are widely scattered in the entire cranial vault. There are also neither signs of bone sclerosis nor thinning of the cortex around the osteolytic lesions.

\section{PALAEOPATHOLOGICAL DIAGNOSIS}

The cause of the extensive pathological changes, i.e. many diffused punched out lesions in the skull of Muen-40, may be attributed to one of the following diseases :

1) Osseous syphilis

2) Secondary metastatic carcinoma

3) Multiple myeloma

Osseous syphilis frequently causes considerable pathological changes in the skull. However, these changes are characterized by gummatous bone necrosis, the stellate scars formed by new bone production and the coalescing of many destructive syphilitic perforation with partial bone sclerosis (see STEINBOCK, 1976). In this case, however, there are no 
such characteristic signs of osseous syphilis in the skull of Muen-40. Hence the diagnosis of osseous syphilis can be excluded.

The differential diagnosis between metastatic carcinoma and multiple myeloma is very difficult, because the pathological features caused by these two malignant tumors of ten represent quite similar conditions in the dry bones. BROTHWELL (1967) noticed as follows, " Such changes are not inconsistent with myelomatosis but nor are they with secondary metastases.". At present, there are few palaeopathological studies enabling us to make distinction between multiple myeloma and secondary metastatic carcinoma. In general, the cases of multiple myeloma often make the diffused clear rounded lytic lesions, while the secondary malignant carcinoma produce relatively large and restricted defects in the skull.

Roentgenological examinations would be helpful in diagnosing all the palaeopathological tumors of skeletal remains. Also in this case, the roentgenogram has made the diagnosis more reliable. There are many diffused punched out lesions without any bone sclerosis on the roentgenogram, which is the characteristic and important evidence for diagnosing this case as multiple myeloma.

\section{DISCUSSION}

The essential feature of multiple myeloma which have been discussed recently by many authors is a malignant proliferation of plasma cell originating from bone marrow. The bones most frequently affected are the cranium, ribs, vertebrae and pelvis. The incidence of multiple myeloma increases progressively with age, the highest rate being over the age 80 in male and over 70 in female (BERGSAGEL, 1977). In all the cases of multiple myeloma, the patients are inevitably subject to die within 2-5 years.

The clinical manifestations are characterized by severe anemia, hyperglobulinemia, Bence-Jones protein in urine and remarkable bone changes in roentgenogram. In the present day, about 90 per cent of the cases examined show the bone changes such as osteoporosis, punched out shadow and poorly circumscribed bone destructions etc. in myelomatosis (IMAMURA, 1968 \& 1978; NISHIOKA, 1971). In particular, the osteolytic punched out lesions are characteristic and reveal severe destructive bone changes.

The annual incidence of multiple myeloma per 100,000 population has been estimated to be 0.09 in 1958, 0.37 in 1967 and 0.46 in 1977 in Japan. The incidence of myeloma is obviously higher in Europe and U.S.A. than in Japan, although the incidence is evidently increasing progressively in this country.

From the palaeopathological point of view, fourteen possible cases diagnosed as multiple myeloma have been reported in the world. Recently, BROTHwELL (1967) and Steinbock (1976) have collected these reports and arranged them in order. BROTHWELL pointed out the difficulties to make a differential diagnosis between the secondary metastatic carcinoma and multiple myeloma palaeopathologically. $\mathrm{He}$ 
is of the opinion that most cases reported previously should be regarded as those of metastatic carcinoma.

Thus the individuals of multiple myeloma diagnosed accurately seem to be limited to a few cases. There are two specimens(USNM 242559 \& USNM 290064) diagnosed palaeopathologically as multiple myeloma by STEINBock (1976). He described circumstantially the morphological findings of the pathological changes in the skull and post cranial skeleton.

\section{CONCLUSION}

Concerning the destructive lesions in the skull of an adult male in the Edo period of Japan, the diagnosis is palaeopathologically made as multiple myeloma from the morphological findings and roentgenological examinations. However, there still remain some problems to be solved in order to make the differential diagnosis more exactly.

This is the first report on a palaeopathological case showing a malignant neoplasm of the human bone excavated from Japan.

\section{ACKNOWLEDGMENTS}

The author is deeply indebted to Professor Shigeru Morita of the Department of Anatomy, Jikei University School of Medicine, Tokyo, for permitting to examine the materials under his collection and for his helpful suggestions.

The author also wishes to express his gratitude to Dr. Susumu KATO and Mr. Shuji Takeuchi of the Department of Anatomy, Jikei University School of Med- icine, for their encouragements and advices.

The author's sincere thanks are expressed to Professor Kazuro Hanihara of the Department of Anthropology, Faculty of Science, The University of Tokyo, for his continuous support and advice.

\section{REFERENCES}

ACkerknecht, E. H., 1953: Palaeopathology: a Survey. In: Anthropology Today, pp.120127, Chicago University Press. cited by BRothWELL (1967).

Bergsagel, D. E., 1977: "Plasma cell myeloma" in W. J. Williams, et. al. (ed.): Hematology, pp. 1099-1126, McGraw-Hill, New York.

Brothwell, D. R., 1961: The palaeopathology of early British man. J. Roy. Anthrop. Inst., 91: 318-344.

—, 1967: "Evidence for neoplasms" in D. R. BROTHWELL and A.T. SANDISON (ed.): Disease in Antiquity, Thomas, Springfield.

IMAMURA, Y., 1968: The bone changes in myeloma. J. Medicina. 5 (in Japanese) .

1978: Abnormalities of serum protein. J. Diagnosis and Treatment, 66: 22052210. (in Japanese)

KAwAGOE, T., 1957: Anthropological Studies on the Skulls Edo-era excavated at YushimaMuenzaka, Tokyo. Mem. Department of Anatomy, Vol. 16, Jikei University School of Medicine., Tokyo. (in Japanese)

КовауASHI, K., 1967: Trend in length of life based on human skeletons from prehistoric to modern times in Japan. J. Fac. Sci. Univ. Tokyo, Sec. V (Anthropology), 3(2): 107-160.

KrogmanN, W.L., 1973: The Human Skeleton in Forensic Medicine, pp. 76-91, Thomas, Springfild.

Martin, R., and K. SAller, 1957: Lehrbuch der Anthropologie, Band I, 3 Auflage, Stuttgart, Gustav Fisher.

Morse, D., 1978: Ancient Disease in the Mi- 
dwest. Ill. State Mus. Invest. 15 Springfield. Illinois.

Morita, S., and T. KAwAGoe, 1960: Anthropological studies on the skulls of Edo-era excavated at Yushima-Muenzaka, Tokyo. (A Supplement). J. Anthrop. Soc. Nippon, 67: 38-56 (in Japanese)

NaKaO, K., 1974: The Text of Internal Medicine, vol.2, pp. 445-450, Nakayama Shoten, Tokyo. (in Japanese)

Nishiok A, K., 1971: The Bone in Systemic Disease., pp.94-112, Igagu Shoin, Tokyo. (in Japanese)

Ritchie, W.A., and WARren, S. L., 1932: The occurrence of multiple bony lesions suggesting myeloma in the skeleton of preColumbian Indian. Amer. J. Roentgenol., 28, 622.
Steinbock, R. T., 1976: Palaeopathological Diagnosis and Interpritation., 316-401. Thomas, Springfield.

. Suzuki, T., 1978: A palaeopathological study of the vertebral columns of the Japanese from Jomon to Edo periods. J. Anthrop. Soc. Nippon. 86: 321-336 (in Japanese)

TAKatsuki, K., 1974: " Plasma cell myeloma", ABE, et.al. (ed.)., Practice of Internal Medicine, 496, Igaku Shoin, Tokyo. (in Japanese)

Vital Statistics, 1977: Health and welfare statistics and information. Vol. 1, 100-101, Minister's secretariat, Ministry of Health and Welfare, Tokyo.

Wells, C., 1964: Two mediaval cases of malignant disease. Brit. Med. J., 1: 1611.

(Received May 20, 1980)

江戸時代日本人古人骨における多発性骨骾腫についての古病理学的研究

\author{
鈴 木 隆 雄 \\ 東京大学理学部人類学教室
}

骨に対して，著しい形態学的あるいは病理学的な変化を及ぼす腫瘍，なかでも悪性腫瘍は，古人骨において その発見例は非常に少なく, 研究むあまり進んではいない。日本においても, 古人骨の古病理学的研究の報告 は数例があるが，現在までのところ恶性腫瘍に関する報告はまだ一例もなされていない。

今回筆者は, 江戸時代人頭蓋の古病理学的検索の中で骨䯣に原発する悪性腫瘳の一つである多発性 骨䯣腫 (multiple myeloma) と診断される興味ある一例に遭遇したので報告する。

この著明な病理学的所見を示す頭蓋は, 1955年東京慈恵会医科大学第一解剖学教室の川越逸行博士により， 東京都文京区晹島の然縁坂の工事現場加発見され収集された約 300 個の頭蓋の一つで, “Muen-40”のラ ベルのあるものである。

頭蓋全体に搛慢性に拡がる約20個の直径約 3-8 $\mathrm{mm}$ の小孔が認められ，辺縁は鋭く，治療傾向はない。頭蓋 X線像では無数の小円透亮像, いわゆる “打ち抜き像 punched out lesion” が認められ, 辺縁の硬化像等 はない。乙のような肉眼的，X線学的な特徵は，多発性骨䯣腫の像によく一致している。

鑑別診断としては，骨梅毒症，二次性悪性腫瘍転移等が考えられるが，なかでも悪性腫瘍転移との鑑別は困 難な場合が多い。しかし悪性腫瘍転移の場合は病変がより大きく，また限局した病巣をもつととなどが知られ ている。従って本例の場合は, 古病理学的に, 熟年男性の多発性骨䯣腫であると診断された。 